\title{
REFORM IN CRIMINAL PROCEDURE
}

THE recent enactment of a bill to give the Supreme Court rule-making power to draft a code of criminal procedure for the federal judiciary ${ }^{1}$ has focused attention on the general status of reform in criminal procedure in this country. Criminal procedure-encompassing pre-trial and trial procedure, and appeals - concerns a relatively insignificant aspect of criminal administration, and procedural reform alone can scarcely be expected to provide a solution to the crime problem. ${ }^{2}$ Existing inadequacies in police, parole and penal administration, for example, will dwarf considerably any profit which might be anticipated from this particular reform. ${ }^{3}$ Fundamentally, moreover, correction of crime evils lies deeper than any of these items, for it is bound up with environmental and psychological factors which are only now being scientifically investigated and which may be affected by nothing short of a

1. Pub. L. No. 675, 76th Cong., 3d Sess. (June 29, 1940). Federal criminal proceedings subsequent to verdict or plea of guilty have since 1934 been regulated by Supreme Court rules promulgated pursuant to Act of Congress, 47 Srst. 904 (1933), as amended, 48 STAT. 399,28 U.S.C. \$723a (1934), and are not, properly spealing, covered by Pub. L. No. 675. See Orfield, Federal Criminal Appcals (1936) 45 YasE L. J. 1223; Comment (1939) 52 HARv. L. REv. 983. But until the formulation of appropriate rules under this new Act, federal criminal procedure prior to verdict or plea of guilty will continue to be governed in part by specific statutory provisions, and in part by Section 722 of the Revised Statutes (28 U.S. C. $\$ 729$ ), which in effect requires conformity to the common law as modified and changed by the constitution and statutes of the state in which the federal court is held. The few federal statutes of general application deal with points which are for the most part minor in character, such as the joinder of counts in an indictment; the effect of a judgment on demurrer; procedure in removal hearings; and the issuance of search warrants. Consequently it is necessary on most points to follow state procedure, with considerable confusion and lack of uniformity as a result. See Hearings bcfore House Committee on Judiciory on H. R. 4587, 76th Cong., 1st Sess. (1939) 3, 8.

With the passage of this Act, the entire field of federal judicial prosedure has bren brought within the rule-making power of the Supreme Court. 47 Srar. 904 (1933), as amended, 48 SтAт. 399, 28 U.S.C. \$723a (1934) (criminal appeals); 48 Stat. 1054, 28 U. S. C. $\$ 723$ (b-c) (1934) (civil actions); 1 Sтภт. 93 (1789), 28 U. S. C. $\$ 723$ (1934) (equity and admiralty cases); 30 SrAT. 544 (189S), 11 U. S. C. $\$ 53$ (1934) (bankruptcy). Historical and practical arguments for the rule-making power can be found in Warner and Cabor, Judges and Laiv Reforar (1936); Pound, Praclical Advantages of Rules of Court for Criminal Procedure (1939) 25 A. B. A. J. 825. Note particularly the comprehensive monograph, Rule-Jaking Poucer in New Yorls (1939) Fifth Annual Report and Studies of N. Y. State Judicial Councti. 271.

2. See United States Nat. Cossar. on Law Observance and E:ifoncenenit, Report on Criminal Procendre (1931) 2-5 (hereafter cited as Wickersunuas Cossmission); Frankfurter and Corcoran, Petty Fcderal Offerses and the Constitutional Guaranty of Trial by Jury (1926) 39 HARv. L. Rev. 917-919.

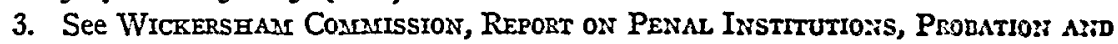
Parole (1931); id., Report on Police (1931); id., Refort on Lawlessiess in Law ENFORCEMENT (1931). 
general social rearrangement. But within its admittedly modest range of operation, criminal procedure presents wide scope for beneficial improvement.

It is customary to regard procedural reform as a streamlining operation. But this ideal, which has proved so successful in the case of civil procedure, constitutes a real danger in the reform of criminal procedure. The latter must serve a two-fold objective: it must not only provide speed and efficiency of administration, but it must also safeguard the interests of a multitude of uncounselled "little people" for whom a system of speed and efficiency spells the risk of hasty conviction of the innocent. ${ }^{4}$ For many defendants, criminal justice is already too speedy. The guaranty of assistance of counsel $;$ the elimination of extra-legal, short cut methods of police questioning ${ }^{6}$ the reduction of appeal costs so as to make the right to appeal less academic : ${ }^{7}$ these, perhaps even more than speed and efficiency, are among the appropriate ideals of a reform movement in criminal procedure. In view of these considerations, the task of reforming civil procedure should be sharply distinguished from the task of improving criminal procedure. ${ }^{8}$

\section{Pre-Trial Procedure}

The ambitions and accomplishments of the reform movement in criminal procedure can be viewed concretely in the model code drafted in 1930 by the American Law Institute and adopted with slight modification by numerous

4. See Wickershan Commission, Report on Lawlessness in Law EnforceMENT (1931) 273-278; Dunn, Our Dangerous Criminal Procedure (1940) 30 J. Crin. L. AND CRIM. 888.

5. Cf. Wickersham Commission, Report on Lawlessness in Law Enforcenent (1931) 281-283. See Hearing before Senate Committee on the Judiciary on S.1845 and $S .2871$, 76th Cong., 3d Sess. (1940), bills to provide public defender system for United States district courts; Smith and Bradway, Growth of Legal Aid Work in the United States (1936) U. S. Bureau of Labor Statistics Bull. No. 607 71-96; Calif. Univ. Bur. of Pub. Admin., The Public Defender and Private Defense Atrorners (1935).

Although so widely espoused by liberal thinkers, the public defender system should not be accepted without question as the ultimate to be desired. Greater potentialitics may exist in a system of assigned counsel so conducted as to call upon the energies of the junior members of the bar, for a nominal fee or one paid by the state.

6. See note 25 infra.

7. See pp. 116-117, and note 57 infra.

8. This distinction is not usually recognized. Thus, in signing the Act which gives the Supreme Court rule-making power over criminal procedure, President Rooscvelt said: "It is hoped this grant of power will result in introducing uniformity and simplicity in the administration of criminal justice in the federal courts and eliminating some of the archaic technicalities which at times hamper or delay the progress of cases through the courts. . . . The Rules of Civil Procedure have met with general acclaim and have made an important contribution to reducing law's delays and diminishing the cost of litigation. It is reasonable to expect a similar result in criminal cases from the legislation just enacted." (1940) 9 U. S. L. WeEK 2032. 
state governments. ${ }^{9}$ These codes effect no essential changes from former practice in the preliminary stage of criminal procedure, which relates only to determination of probable cause sufficient to warrant detention of the accused for trial, and embodies the functions of magistrate, prosecutor, and grand jury. ${ }^{10}$ The last is steadily falling into disuse as a result of a long campaign, endorsed by the new codes, to replace indictment, at least as an everyday device, with the presumably speedier, less costly, and more convenient information filed by the prosecutor. ${ }^{11}$

A concomitant of the reform agitation for the replacement of indietment by information - with its consequent elimination of the grand jury and broadening of the scope of the prosecutor's discretion-is a fear of the potentialities which exist for abuse of this discretion. ${ }^{12}$ It is frequently argued by proponents of the information procedure that the desired check on the prosecutor could be supplied by the preliminary hearing..$^{13}$ But magistrates and justices of the peace, who are frequently scattered throughout the county and ill versed in law as compared with the prosecutor, are mure likely to be dominated and overridden by the latter than to exercise an effective checking influence. ${ }^{14} \mathrm{~A}$ more concrete proposal for checking the prosecutor is found in the A.L.I. provision that a prosecution shall not be dismissed except by court order and "for good cause" amplified in a written statement to be

9. A tabular analysis of legislative recognition accorded the A.L.I. code up to June 30, 1936, appears in XIII Proceedrasgs of The Asrerican LAW Isstrutre (1935-1936) 103-108. The extent of its adoption by the States from 1935-1938 is noted in Cnnse Control-State Laws, 1935-1938, State Law Dig., Rep. No. 3 (Library of Congress 1940) 41-42. A notable event in the more recent history of the A.L.I. code is the promulgation by rule of court of a new code of criminal procedure for Arizons, effective April 1,1940, and virtually identical with the A.I. I. code.

Mention should be made of the valuable studies of criminal procedure conducted by judicial councils, a phenomenon of the last 15 or 20 years. A list of the states with judicial councils as of 1938 appears in PENN. JT. Legrs. Cosas. Refors, infra note 36, at 103.

10. Special note may be made of the reform in $\$ 12$ of the A.L.I. code authorizing the substitution of summons for arrest whenever it is reasonably certain that the defendant will appear on such notice. For the progress of this reform by 1928, see the A.L.I. Cone of Crminnal Procedure, Tentative Draft No. 1 (1928) 133-136. For pleas in favor of the reform, see WARNER AND CABot, op. cit. sipra note 1, at 148-151; Cuenzlatid Foundation Survey of Crintinal Justice in Cleveland (directed and edited by Pound and Frankfurter) (1922) 202-203.

11. A leading campaigner is Raymond Afoley; see his The Initiotion of Criminal Prosecutions by Indictment or Information (1931) 29 MIICH. L. REv. 403; cf. Clevelnso SURVEY, op. cit. supra note 10, at 210-212. MLoley's position has been challenged by Dession, From Indictment to Information-Implications of the Shift (1932) 42 Y MLE L. J. 163; and Hall, Analysis of Criticisms of the Grand Jury (1932) 22 J. Crns. L. AND CRAS. 692.

12. See Wickershays Commission, Report on Prosecutiox (1931) 1S-20.

13. See authorities cited supra note 11.

14. See Dession, supra note 11, at 172; Moley, Our Crisrnatal Courts (1930) C. II; cf. Seabury, Investigation of New York City Mlagistrates' Courts (1932). 
entered on record. ${ }^{15}$ This provision, however, may be as misguided as it is well-intentioned. Indeed, several persuasive arguments can be made for preserving the prosecutor's discretion in all its amplitude. In the first place he cannot prosecute all offenses, as he operates on too limited a budget. ${ }^{10}$ If he undertakes a prosecution and later discovers that it is less worthy of his resources than originally supposed, he should be able to drop it without the embarrassment of an open inquiry in court. Secondly, there are a number of cases he will not want to prosecute because only a personal grudge, and not the public interest, will be served thereby; and again, he should be able to drop a case which, if better advised earlier, he would not have undertaken. Finally, it is only in the privacy of his office that he can conduct the plea bargaining which, although viewed as unethical in many quarters, is a highly useful as well as usual procedure in criminal administration. ${ }^{17}$

Opportunities for abuse of the prosecutor's discretion are said to be found particularly in the twentieth century metropolitan setting, where the check of an informed local opinion may be absent. ${ }^{18}$ In such areas, some check may indeed be desirable; but the best equivalent of "an informed local opinion" would seem to be not a weak preliminary hearing or an embarrassing court supervision, but the institution of the grand jury, ${ }^{10}$ for which the new codes still generally continue to make some rather ambiguous provision. ${ }^{20}$

Although in most cases it may be ill-advised to hedge the prosecutor's power to nolle, it need not follow that he should be left to conduct his inquiries alone. Completely unhampered, he would also be completely deprived, in investigating probable cause, of those aids which are or could be made avail-

15. Section 295. A suggestion is made to this effect in Missours Crime Survey (1926) 370-371.

16. Cf. Wickersham Commission, Report on Prosecution (1931) 104. Sce also their Report on The Cost of Crime (1931).

17. "The ideal that all laws should be enforced without a discretionary selection is impossible to carry out. . . The prosecutor . . . will be confronted with a long line of offenders caught in the net who are unimportant, but who must be disposed of. His choice will be either to make reasonable compromises with them, or else to clog the machinery with relentless prosecution of comparatively harmless persons." Arnold, Lawe Enforcement-An Attempt at Social Dissection (1932) 42 YaLE L. J. 1, 9. Sce to the same effect, A.L. I., A Study of the Business of the Federal Courts, Pt. I: Criminal Cases (1934) 57; Dession, supra note 11, at 192.

18. Credit for this idea goes principally to Dean Pound. See Pound, Cruminal Justice in AMrerica (1930) 149-151; Cleveland Survey, op. cit. supra note 10, at 328-329.

19. See Dession, supra note 11.

20. The A.L.I. Code, for example, contains long detailed sections ( $\$ 118-147$ ) governing grand jury practice; yet, the provision ( $\$ 114$ ) that a grand jury shall be summoned when in the judge's opinion "public interest so demands," except that it must be summoned "at least once a year in each county," does not promise that it will be much used. $C f$. note 32 infra.

All the new codes, of course, reject the old type indictment and sponsor the socalled "short form," A. L. I. Code, $\S 152$. See Comments (1935) 23 K.y. L. J. 362; (1937) 35 MICH. L. REV. 456. 
able through the devices of preliminary hearing and grand jury.21 The preliminary hearing-if held at all-is generally a cursory affair shortly aiter arrest at which the magistrate, if he decides to detain the accused, fixes bail 22 and performs other similar functions. This brief hearing serves some useful purposes, such as providing an opportunity for getting the stories of witnesses on oath and formal record-a particular advantage where the grand jury has fallen into disuse as a regular part of the procedure. Furthermore, it provides the defense honestly unable to anticipate the charges against it with an early occasion-perhaps too early if the State's case is not at all prepared-on which to force the prosecutor's hand. But the preliminary hearing has been plainly inadequate as an energetic investigatory device. ${ }^{23}$ Compare, for example, the Continental procedure. This consists of an examination conducted by the juge d'instruction, an impartial judicial officer entrusted with the primary responsibility of bringing out the evidence necessary for a determination of probable cause, and endowed with broad powers to this end. He may visit the scene of the crime and make searches and seizures, summon and hear witnesses, appoint experts to conduct special investigations, and finally, interrogate the suspect. At the conclusion of his inquiry he may dismiss the case or else make recommendations for a trial to the chambre d'accusation, a three-judge court which, on the basis of his written report and briefs of both sides, decides whether or not the trial shall be held.2-

Something comparable to the well implemented preparatory stage ${ }^{25}$ in Continental proceedings might be developed out of the preliminary hearing

21. Investigation would be greatly aided by a correction of the extreme decentralization and want of cooperation between jurisdictions which characterize so much prosecution throughout the country today. For an insight into this problem, which falls somewhat outside the scope of an article on criminal procedure, see Wicrensunas Co:sxissston, Report on Prosecution (1931), particularly at 6-18. See also Leflar, The Future of Criminal Procedure in Arkansas, Forty-Szcond Ann. Proc'gs of Bar Assoc. of Arransas (1939) 291, 293-294; Criare Controz-State Lays, 1935-1938, State LAW DIG., ReP. No. 3 (Library of Congress 1940) 40-41.

22. Bail-fixing marks still another chapter in reform. See c. 3 of A. L. I. code, with the accompanying commentary at 252 et seq. of Tentative Draft No. 1 (1928). See Comments in Cleverand SURveY, op. cit. supra note 10, at 290-292; Moley, Bail Bords, Míssourd Crrme SuRvey (1926) 187-218; and in general, Hayes, Contraets to Indemnify Bail in Criminal Cases (1937) 6 FordHasr L. REv. 387.

23. Moley, Our Crarninal Courts (1930) 14-36; Dession, sipra note 11, at 166-175.

24. The Continental procedure is described in Keedy, The Prcliminary Irazestigation of Crime in France (1940) 88 U. of PA. L. Rev. 385, 692, 915; see also Ploseowe, The Development of Present-Day Criminal Procedures in Europe and Anscrica (1935) 48 Harv. L. Rev. 433; Auld, The Comparatize Jutrisprudence of Criminal Process (1935) $1 \mathrm{U}$. of ToRonio L. J. 82. The sentiments of the American Lav Institute on this question are set forth in its Code of Criminal Procedure, Tentative Draft No. 1 (1928) 26-27.

25. It has been persuasively argued that with a strengthened procedure for preliminary investigation the necessity for disorderly and illegal "third degree" methods will disappear. See Dession, supra note 11, at 191; Comment, The Privilege Against Self-Incrimination (1940) 49 YALE L. J. 1059, 1071; and in general, Wickersesar Cosnsission, 
in this country, but only by the introduction of radical changes in the personnel of the magistracy ${ }^{26}$ and by the drastic modification of the privilege against self-incrimination so as to provide a legal basis for an effective questioning of the accused. ${ }^{27}$ Short of such a drastic reform, however, it is necessary to rely on the Anglo-American institution of the grand jury. Indeed, the grand jury, much more than the preliminary hearing as it now exists, seems to have the potential effectiveness of the examination by the juge d'instruction, and to present a fertile field for development along those lines. Principally through its $e x$ parte character and its subpoena power, the grand jury can even now supply valuable everyday aids to the prosecutor's investigation. ${ }^{28}$

Because of its positive merits, the grand jury has managed to outlive its critics and survive the rather vigorous campaign waged against it ever since the beginnings of public prosecution. ${ }^{29}$ Not only does it persist, but it currently displays unmistakable vitality in federal anti-trust prosectutions, ${ }^{30}$ for example, as well as in criminal prosecutions in such important metropolitan areas as New York City. ${ }^{31}$ Notwithstanding substitution of the information for the process of indictment, the new codes seem to recognize some of this merit in the grand jury, without apparently being prepared to say precisely in what the advantages consist. ${ }^{32}$ Such ambiguity-whether it betrays indecision, lack of courage, or an unjustifiable complacency - may be taken to represent the attitude of the drafters of the new codes towards the pre-trial stage in general. The significant crime surveys undertaken in the 'twenties by experts in numerous American states and cities, ${ }^{33}$ in their picture of the

Report on Lawlessness IN LAw ENFORCEMENT (1931) 173-180. But see Warner, How Can the Third Degree be Eliminated? (1940) 1 BILL of Rights Rev. 24 (pointing out that the French procedure has not entirely eliminated the use of the third degrec, and calling attention to the orderly English system which suggests that the remedy is to obtain "police and prosecutors who prefer not to use [the third degree] and who are able to protect the public without resorting to it").

26. See note 14 supra.

27. See Comment, The Privilege Against Self Incrimination (1940) 49 YALE L. J. 1059. On the right of the defendant to make a statement before the magistrate, see A.L.I. Tentative Draft No. 1 (1928) 206-210; cf. Report of Comm. on the Aduin. of Justice in N. Y. State: Revision of the Code of Criminal Procedure (1939) 43-46.

28. See Dession and Cohen, The Inquisitorial Functions of Grand Juries (1932) 41 Yale L. J. 687; Note (1938) 17 N. C. L. Rev. 43.

29. Jeremy Bentham is frequently quoted as saying in 1825 that the grand jury had outlived its usefulness for over a century.

30. See Lewin, The Conduct of Grand Jury Proceedings in Autitust Cases (1940) 7 Law \& Contemp. Prob. 112.

31. See The Panez, publication of New York Grand Jurors' Association.

32. See Brunyate, The American Draft Code of Criminal Procedure, 1930 (1933) 49 L. Q. Rev. 192, 197-198. See note 20 supra.

33. These surveys are summarized by, and climaxed in, the Wickersham Reports. The first survey was undertaken in Cleveland in 1922, and to its success must probably be attributed the series which ensued. 
inadequacies and the crucial importance of this stage, ${ }^{3 t}$ clearly reveal the shortcomings of such an attitude.

\section{TrIal Procedure}

The criminal trial approaches its objective of determining guilt in a far more satisfactory manner than does the preliminary stage in meeting its objective of ferreting out probable cause. ${ }^{35}$ Nevertheless, when early in the century a movement arose for reform in criminal procedure, it was with the actual trial itself that the reformers were mainly concerned. The movement was a reaction against alleged technicality in trial practice which was believed to operate unduly to the defendant's advantage. A handful of patchwork reforms was therefore proposed with a view to tipping the scales into correct balance. ${ }^{36}$

This program of reform, although the subject of considerable publicity for over a quarter of a century, ${ }^{37}$ has not been universally accepted nor even wholly agreed upon among the reformers themselves. Certain reform tendencies, however, are clearly discernible in all the new codes. Thus, in line with the general trend to eliminate "surprises" from the defendant's case, the Arizona code adopted this year - an almost complete replica of the A.L.I. model - provides that written notice of intention to claim the

34. This stage disposes of an overwhelming proportion of cases. FALL, THEFT, LAW AND SoCrETy (1935) 113; see also the surveys mentioned supra note 33.

35. See Warner and Cabot, Changes in the Administration of Criminal Justice During the Past Fifty Years (1937) 50 HARv. L. Rev. 583, 593.

36. "For many centuries the chief development in criminal procedure was securing for the defendant an adequate opportunity to present his defense. Notable landmarls in this direction were supplying him with a copy of the indictment, permitting him to have counsel and witnesses sworn and summoned to appear, and finally allowing him to take the stand as a witness in his own defense. It was necessary also to reduce the severity of punishments for crime, which in the early part of the nineteenth century were far in excess of what the public approved. While these processes were going on, many judges seized upon technicalities as an $a d$ hoc means of saving defendants from punishments approved of neither by them nor by their contemporaries.

"By 1886, punishments for crime had been brought into line with community opinion, and defendants had secured the legal rights necessary for an adequate defense. However, mental habits change slowly, and a strict attitude on technical points long survived the reason for its existence." Id. at 587. For an example of the reforms proposed to neutralize this technicality, see MacChesney, $A$ Progressize Program for Procedural Reform (1912) 3 J. CRns. L. AND CRns. 528; Mfillar, The Mrodernization of Criminal Procedure (1920) 11 J. Crins. L. And Crasr. 344; and compare Repont of Sectio: o: Reform of Civil and Crartnal Procedure of Bar Assoc. of Sam Francisco (1910), with Jx. Legis. Conras. on the Adarn. of Crminal Justice, Report to the Goverson of Pennsylvania (1938). The importance of these reforms is easily over-emphasized. Warner and Cabot, sitpra, at 589. And the hyper-technicality of the last century has been definitely on the wane, see Pound, op. cit. sipra note 18 , at 165 , but is still a subject of comment, see Address by Circuit Court Judge Patterson at Harvard Clubs dinner, N. Y. Times, Mray 19, 1940, p. 45, col. 3.

37. See note 36 stipra. 
defense of insanity or to establish an alibi must be given several days before trial. $^{38}$ In the matter of peremptory challenge of jurors, the number allowed the State is equalized with that allowed to the defendant so as to correct the State's previous disadvantage; if two or more defendants are jointly tried, the State is allowed as many challenges as are allowed all the defendants combined. ${ }^{39}$ Further popular jury reforms followed by Arizona are provision for alternate jurors ${ }^{40}$ and more careful selection of jurors. ${ }^{41}$ The Arizona code, however, does not empower the judge to comment to the jury on the evidence and credibility of witnesses, a reform which is a conspictuots feature of federal procedure and of the model A.L.I. code. ${ }^{42}$ Neither does Arizona recognize the A.L.I. provisions allowing waiver of jury trial ${ }^{48}$ and approving fraction verdicts in all but capital cases. ${ }^{44}$ And there is no reference in either code to comment on failure of the defendant to take the stand, another lack which is conspicuous in view of the barrage of contemporary discussion. ${ }^{45}$

38. Section 233. See Stayton and Watkins, Is Specific Notice of the Defense of Alibi Desirable? (1940) 18 TEx. L. REv. 151; (1935) 21 VA. L. Rev. 940; (1935-1936) $26 \mathrm{~J}$. CRIM. L. AND CRIM. 454. A bill to require advance notice of alibi defense in the federal system is now pending in Congress. S:187 and $H . R .1995$.

39. Sections 279,280 . See elaboration of existing state law, A.L. I. Code, Tentative Draft No. 2 (1929) 298-315; see also (1936) 10 So. Calif. L. Rev. 89.

40. A. L. I. Code $\$ 285$, with which compare Arizona Code $\$ 282$. See A. L. I. commentary in the Proposed Final Draft (1930) 167-168; see also Warner ANd Cator, op. cit. supra note 1, at 90; (1936) 24 CALIF. L. Rev. 735.

41. See A.L.I. Code, c. 13, with commentary in Tentative Draft No. 2 (1929) 265-272. See PenN. Legrs. Report, op. cit. supra note 36, at 50-51; Hearings on RulcMaking Bill, op. cit. supra note 1, at 9-12; Duncan, Proposed Changes in Florida Criminal Procedure (1936) 10 Fta. L. J. 362, 365-366. On special juries, see N. Y. STATE JudtctaL Council, Fifte Annual Report (1939) 42-43; Mass. Judicial Council, Tentil AnNual, Report (1934) 44-46.

42. Section 325 A. L. I. On federal practice, see (1934) 8 So. Chl.rf. L. Rev. 46. Note the general commentary in N. Y. State Judictal Council, Fiftir Annual Report (1939) 185 (including at 193 a table showing the present status of comment by judge to jury in 48 states); see also Mrssouri Crine Survey (1926) 363.

43. A. L. I. Code $\$ 266$. See Perkins, Proposed Jury Changes in Criminal Cases (1930-1931) 16 Iowa L. REv. 20, 223. "The infuence of the jury is now relatively minor, due to perhaps the most important single change in criminal law administration, namely, jury waiver. The decline of this ancient institution in the United States during the present century . . . has concentrated the administration of the criminal law in the courts and, even more, in the prosecuting attorneys." HALL, op. cit. silpra note 34, at 112-113. See N. Y. State Judictal Counctr, Fifth Annual Rerort (1939) 153-178, for an excellent monograph on jury waiver treating the law in all American jurisdictions. See also, in general, Von Moschzisker, The Historic Origin of Trial by Jury (19211922) 70 U. of PA. L. Rev. 1, 73, 159; Oppenheim, Waiver of Trial by Jury in Criminal Cases (1927) 25 MrCH. L. Rev. 695; (1939) 12 So. CALIF. L. Rev. 207; cf. Frankfurter and Corcoran, supra note 2.

44. A. L.I. Code $\$ 355$, with which compare Arizona Code $\$ 348$. See A. L. I. commentary in the Proposed Final Draft (1930) 319-324; see also Missourr Crrme Sunver (1926) 366-367 and (1931) 17 VA. L. Rev. 497.

45. See controversy between Reeder, Comment Upon Faihure of Accused to Testify (1932) 31 Micr. L. Rev. 40, and Bruce, The Right to Comment on the Failure of the 
The reluctance with which the states are adopting these modest suggestions for reform bodes ill for any more basic program. It can hardly be doubted that there is need for drastic modification of a criminal trial procedure which substantially retains its form and function as inherited from the early days of the common law, ${ }^{46}$ notwithstanding an entirely changed conception of the average offender. The present general objective of the trial proceeding, determination of the guilt or innocence of the accused as a prelude to disposition of the guilty in prison or asylum, must some day undergo modification in harmony with the new emphasis away from punishment to understanding and correction. ${ }^{47}$ Probably the criminal administration for which present-day thinkers are striving will be rationalized along the lines of something analogous to a department of public health. ${ }^{48}$ A centralized system of files would acquaint both prosecutor and judge with the unique problem presented in each particular case of delinquency, far better than this can be done at present. Data for such files would be culled from the reports of social agencies as well as of courts and their adjuncts, and case histories prepared by psychiatrists would also be available. The trial itself ought to develop into a truly omnibus proceeding, omnibus not only in its consideration of lines of causation, but also in its determination of matters collateral to the guilt and disposition of the defendant. Such collateral matters include provision for dependents of the accused, redress for the victim of the crime through damages or by ordering the defendant to repair damage done, and perhaps, in cases

Defendant to Testify (1932) 31 IIrch. L. Rev. 226. See also N. Y. Stute Jentcul Council, Third ANNuAl Report (1937) 259-276; Comment (1940) 49 Yale I. J. 1059; Warner AND CABot, op. cit. supra note 1, at 90; (1938) 87 U. of PA. L. REv. in. For the law in the federal courts, see Comment (1939) 33 ILL. L. REv. 586; (1939) 6 U. OF CHI. L. REv. 494; and with Bruno v. United States, 308 U. S. 287 (1939), see S.194 and H.R. 1993, now pending.

46. Pound, op. cit. supra note 18, at 108: "Criminal procedure, as it stands in Blacl:stone's Commentaries, is the system with which we are familiar today." See to same effect, WARNER AND CABOT, sutpra note 35 , at 585 .

47. "Psychiatrists and psychologists are filtering into the administration of Criminal Law with astonishing rapidity. They bring with them an absolutely contrary assumption -that the problem of crime does not concern law enforcement but instead the maladjusted individual." Arnold, supra note 17, at 22. See Harno, Rationale of a Criminal Code (1937) 85 U. of PA. L. Rev. 549; Gausewitz, Considerations Basic to a Neru Peral Code (1936) 11 Wrs. L. Rev. 346, 480; Glueck, Principles of a Rational Penal Code (1923) 41 HARv. L. KEv. 453. So far, the new viewpoint has manifested itself particularly in an individualization of treatment of the offender once his guilt has been determined. See WARNER AND CAEOT, op. cit. supra note 1, at 170 et seq.; WARNER aNid CAror, susprs note 35, at 598 et seq.; Wickershan Conarission, Report os Pexil Institurions, Probation and Parole (1931) 141, 172, 238; (1939) 30 J. Crobs. L asid Carr. 138; Rep. Atr'y Gen. (1939) 6. See also Comment, Declaratory Decisions in Criminal Lazu (1937) 46 YALE L. J. 855.

48. Compare with the following text the very similar procedure of the juvenile courts today. See Cosulich, United States Juventle Court Laws (1939); Sherer, Stoops \& Kennedy, Recommendations for Juvenile Court and Probation Logislation (Report to Conn. Legis. Council 1940). 
involving civil liberties, adjudication of injuries for which the state has been responsible. ${ }^{49}$ When viewed in terms of these sensible objectives, the superficiality of the popular trial reforms becomes readily apparent.

\section{Appeals}

Notwithstanding the obvious necessity for appellate courts to correct errors of law and produce uniformity throughout the jurisdiction, no appeal was permitted at common law in criminal cases. ${ }^{50}$ By force of statute, the defendant may now universally take an appeal, but inhibitions centering largely around double jeopardy notions have considerably slowed down the extension of this right to the prosecution. ${ }^{51}$ The A.L.I. and its daughter codes, in line with the current movement to allow the state at least a limited right of appeal, permit appeal from an order quashing an indictment or information, granting a new trial, or arresting judgment; from a sentence allegedly illegal; and from a ruling on a question of law adverse to the state where the defendant appeals from a judgment of conviction. ${ }^{52}$ But they scrupulously omit appeal by the state from a verdict of acquittal. It is interesting to note that in Connecticut, where alone this practice is sanctioned, ${ }^{53}$ it has been found that the prosecution does not in fact often avail itself of the opportunity. ${ }^{54}$ Nevertheless the threat that it may appeal removes whatever pressure had been felt by trial judges to rule in the defendant's favor on difficult questions as an insurance against the possibility of reversals. ${ }^{.5}$ The existence of the right to appeal, furthermore, gives the state a chance for an earlier ruling than might otherwise be possible on controverted or new matter which is ripe for authoritative decision.

The other significant current of reform which has been sponsored in the matter of appeals is concerned with appeal costs, ${ }^{56}$ and is designed to make

49. Compare the federal and several state statutes providing for indemnity to persons erroneously convicted and imprisoned. See (1938) 52 HaRv. L. Rev. 333.

50. See in general Orfield, Criminal Appeals (1939).

51. See note 53 infra. See also ORFIELD, op. cit. supra note 50; Miller, Appcals by the State in Criminal Cases (1927) 36 YALE L. J. 486; Comment (1938) 17 NED. L. BuL.. 207.

52. A. L. I. Code $\S 428$; cf. Arizona Code $\S 419$. On the problem, in the federal courts, of appeal from a verdict of acquittal on a reserved motion for directed verdict, sce (1940) 49 YALE L. J. 733.

53. See Palko v. Connecticut, 302 U. S. 319 (1937), (1938) 47 YALE L. J. 489, upholding the constitutionality of the Connecticut statute against charges of violation of due process of law.

54. So concludes Professor Dession of the Yale Law faculty, on the basis of a long and close personal association with criminal administration in Connecticut.

55. See WaRner and CaBot, supra note 35, at 588-589; and authorities cited supra note 51 .

56. Other reforms include: speeding up criminal appeals, see A.L.I. provision $\$ \$ 429,430$ (shortening the time for appeal to sixty days-still probably needlessly long); Brunyate, supra note 32, at 204; cf. Beattie, Criminal Appeals in California (1936) 